強く加熱された円管内ガス乱流の二方程式乱流 モデルによる予測*

河村洋**

1.はしがき

管内を流れるガスの乱流を高い熱流束で加熱すると き，熱伝達率が顕著に低下することが知られている。 とくに熱流束が高い場合には，平均温度に対応するレ イノルズ数が通常の臨界值より十分大きくても，乱流 よりもむしろ層流に近い熱伝達率を示す。これを一般 に，層流化現象よよんでいる.

高温ガス冷却型原子㥫 (VHTR) は，高生のへリウ 厶を冷却材とし， $1,000^{\circ} \mathrm{C}$ 程度の高い出口ガス温度を 得ようとする原子炉である。この型の原子炉では，加 熱熱流束が高くかつ炉心内の冷却材流のレイノルズ数 が低いため，層流化現象の発生の可能性が無視でき ず，てれを避けることが熱設計上の制限因子の一つに なっている，そのため，層流化現象について，実験的 にはもちろん，理論的にす検討を行なう必要が生じ， 二方程式型の乱流モデルを用いた解析を試みた，本稿 は，その際の二方程式乱流モデルの使用および改良経 験について報告するむのである.

\section{2. 二方程式乱流モデル}

乱流の現象墖的なモデル化は，一般には乱流レイ， ルズ数が高い場合の理諭に基づいており，分子粘性の 効果㹥無視されている. しかし，粘性の効果は固体壁 の近傍ではむしろ支配的でさえあるため，壁の存在す る系における乱流を扱うには，壁からある程度はなれ た点での流速や乱流エネルギーを境界条件として与え るのが通例である.しかしこの手法は，本報のように 層流をむ含んだ流れには適用できず，近似的にせ上粘 性の效果を導入したモデルを用いる必要がある.

このような試みは, JONES-LAUNDER ${ }^{1)}$ の $k-\varepsilon モ テ ゙$ ル $\left(\varepsilon \simeq k^{1.5} / L\right)$ と, WILCOX-TRACI ${ }^{2}$ の $k-w$ モデル

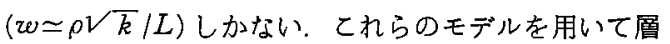
流化現象についてまず予借的な計算を行なったとと

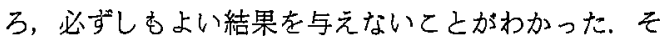

* 辑和 54 年 4 月 6 日，日本航空宇宙学会第 10 期年会シン ポジゥムにて請演. 昭和 54 年 7 月 31 日原䅻受理 Prediction of Strongly Heated Turbulent Flow of Gas in a Circular Tube Using a Two-Equation Model of Turbulence

** 日本原子力研究所 Hiroshi KawamuRa
こで RoTTA ${ }^{3)}$ による $k-k L$ モデルを粘性効果を含む 形记拡張し，とれらろ種のモデルについて比較を行な った.

一般に，とれらの乱流モデルには，むろん多数の経 験的な定数が含まれている。 モデルの提唱者の多く は，非保存的な場合を含む広籍な乱流に対し，普遍的 な一組の定数の存在を期待しているように見える．実 際それはある程度の成功を収めてはいるが，予湘の精 度は必ずしむよくはなく，またモデル化が多くの仮定 を含むことから考えてむ，そのような定数が存在する という保証むない，実用的な観点からはむしろ，それ ぞれの乱流の形状に応じてよく検証された定数の組を 求め，精度のよい予測を行なうほうが有効である。 そ こで本報では，加熱と非加熱の円管内ガス乱流に対し て適用しうる二方程式モデルを得ることを目的とす る.

二方程式乱流モデルを用いて加熱流の計算をするの に先立って，まず等温流に対して妥当な結果が得られ るととを確認する必要がある．そてで，モデルに含ま れる経験定数を再検討し，等温流住対して以下の条件 が満足されるようにした。

（イ）流速，乱流エネルギー，レイノルズ㐫力の半 径方向分布が，それぞれ一般に受け入れられてい る整理式や実験值とはほぼ一致すること.

（口）管摩擦係数が，乱流域で NIKURADSE の式と 大略一致するとと。

（八）物性值を一定としたときの熱伝達率か，乱流 域で $N u=(0.021 \pm 0.001) R e^{0.8} \operatorname{Pr}^{0.4}$ となるこ 亡.

以下ではまず， $k-\varepsilon$ 之 $k-w$ モデルがてれらの条件 を満たすように定数を定め，つついて $k-k L$ モデル に粘性の効果をとり入れるための拡張を行なう，その 後，これらのモデルを加熱ガス流仅適用して既存の実 験結果と比較する。

本報では，レイノルズ応力に対して乱流粘性保数 $\mu_{\mathrm{t}}$ を導入し,

$$
-\rho \overline{u^{\prime} v^{\prime}}=\mu_{\mathrm{t}}(\partial \bar{u} / \partial r)
$$

を仮定する、レイノルズ応力に対してむ輸送方程式を たてて，三方程式型とするてとあ可能である，しか し，ここで扱う内管内流のように軸対称な流れでは 
$\overline{u^{\prime} v^{\prime}}=0$ と $\partial \bar{u} / \partial r=0$ の点が一致するとと，また三方 程式型による予備的な計算でその効果が必ずしす認め られなかったととから，本報では式(1)を仮定した二 方程式型のモデルを用いる.

$2.1 k$-を モデル JONES-LAUNDER ${ }^{11}$ 亿よる $k-\varepsilon モ$ デルは，つぎのように表わされる.

$$
\begin{aligned}
\rho \bar{u} & \frac{\partial k}{\partial x}+\rho \bar{v} \frac{\partial k}{\partial r} \\
= & \frac{1}{r} \frac{\partial}{\partial r}\left[\left(\frac{\mu_{\mathrm{t}}}{\sigma_{k}}+\mu\right) r \frac{\partial k}{\partial r}\right]+\mu_{\mathrm{t}}\left(\frac{\partial \bar{u}}{\partial r}\right)^{2} \\
& -\rho \varepsilon-2 \mu\left(\frac{\partial V \bar{k}}{\partial r}\right)^{2} \\
\rho \bar{u} & \frac{\partial \varepsilon}{\partial x}+\rho \bar{v} \frac{\partial \varepsilon}{\partial r} \\
= & \frac{1}{r} \frac{\partial}{\partial r}\left[\left(\frac{\mu_{\mathrm{t}}}{\sigma_{\varepsilon}}+\mu\right) r \frac{\partial \varepsilon}{\partial r}\right]+c_{1} \frac{\varepsilon}{k} \mu_{\mathrm{t}}\left(\frac{\partial \bar{u}}{\partial r}\right)^{2} \\
& -c_{2} \rho \frac{\varepsilon^{2}}{k}+c_{3} \nu \mu_{\mathrm{t}}\left(\frac{\partial^{2} \bar{u}}{\partial r^{2}}\right)^{2} \\
\mu_{\mathrm{t}}= & c_{\mu} f_{\mu} \rho k^{2} / \varepsilon
\end{aligned}
$$

境界条件は，管壁 $(r=D / 2)$ で $k=\varepsilon=0$ ，管中心 $(r=0)$ で $\partial k / \partial r=\partial \varepsilon / \partial r=0$ である，加熱開始点 $(x$ $=0)$ では， $k$ と $\varepsilon$ は十分発達した等温流の分布をむ つ亡した.

式(2)〜（4)化含まれる定数の值を第 1 表に示す. まず原著者 ${ }^{11}$ による值をテストしたところ，乱流粘性 係数が管中心で最大となり適当でなかった，この点は 比 $\sigma_{R} / \sigma_{\varepsilon}$ を変えることにより改善されることがわか ったので，第 1 表下段のように改訂した，他にむ若干 の変更を行なった。

$2.2 \boldsymbol{k - w}$ モデル WILCOX-TRACI ${ }^{2)}$ によるモデル はつつきのように表わされる。

$$
\begin{aligned}
& \rho \bar{u} \frac{\partial k}{\partial x}+\rho \bar{v} \frac{\partial k}{\partial r} \\
& =\frac{1}{r} \frac{\partial}{\partial r}\left[\left(\frac{\mu_{t}}{\sigma_{k}}+\mu\right) r \frac{\partial k}{\partial r}\right]+c_{G} \rho k\left|\frac{\partial \bar{u}}{\partial r}\right|-c_{D} w{ }^{k} \\
& \rho \bar{u} \frac{\partial w^{2}}{\partial x}+\rho \bar{v} \frac{\partial w^{2}}{\partial r}
\end{aligned}
$$

$$
\begin{aligned}
= & \frac{1}{r} \frac{\partial}{\partial r}\left[\left(\frac{\mu_{\mathrm{t}}}{\sigma_{w}}+\mu\right) r \frac{\partial w^{2}}{\partial r}\right]+c_{1} \rho w^{2}\left|\frac{\partial \bar{u}}{\partial r}\right|-c_{2} w^{3} \\
& -\frac{c_{3}}{\sigma_{w}} w^{3}\left(\frac{\partial}{\partial r} \frac{\rho \nu \bar{k}}{w}\right)^{2}
\end{aligned}
$$

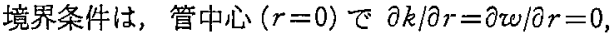
管壁 $(r=D / 2)$ で $k=0, w=\rho u^{* 2} S / \nu$ である、乙こ にS は管壁の粗さ化存する定数で，平滑管に対し ては $S \geq 1,000$ が推罢されている2゙. しかしとの值で は壁近傍のレイノルズ忘力が小さくなりすぎるととが わかったのて，本報では $S=50$ とし，他にも若干の 変更を加えた． また $\sigma_{k}$ む $k-\varepsilon$ モデルにおけると同 様の理由で変更した．その結果得られた定数を第 2 表 に示す.

$2.3 \boldsymbol{k}-\boldsymbol{k} \boldsymbol{L}$ モデルの拡張 ROTTA ${ }^{3)}$ にっって提唱 された $k-k L$ モデルには，粘性の効果は無視されて いる. 以下ではこれに粘性の效果を近似的に導入し， 次の式を提唱する.

$$
\begin{aligned}
\rho \bar{u} & \frac{\partial k}{\partial x}+\rho \bar{v} \frac{\partial k}{\partial r} \\
= & \frac{1}{r} \frac{\partial}{\partial r}\left[\left(\frac{\mu_{\mathrm{t}}}{\sigma_{k}}+\mu\right) r \frac{\partial k}{\partial r}\right]+\mu_{\mathrm{t}}\left(\frac{\partial \bar{u}}{\partial r}\right)^{2}-c_{\mathrm{D}} \rho \frac{k^{1.5}}{L} \\
& -\frac{\mu}{y}\left[\frac{\partial k}{\partial y}\right] \\
\rho \bar{u} & \frac{\partial(k L)}{\partial x}+\rho \bar{v} \frac{\partial(k L)}{\partial r} \\
= & \frac{1}{r} \frac{\partial}{\partial r}\left[\left(\frac{\mu_{\mathrm{t}}}{\sigma_{L}}+\mu\right) r \frac{\partial(k L)}{\partial r}\right] \\
& +c_{1} \mu_{\mathrm{t}} L\left(\frac{\partial \bar{u}}{\partial r}\right)^{2}-c_{2} c_{\mathrm{D}} \rho k^{1.5} \\
& -c_{3} \mu_{\mathrm{t}} \frac{2 L^{3}}{y^{2}}\left(\frac{\partial \bar{u}}{\partial r}\right)^{2}-c_{4} \mu \frac{L}{y}\left[\frac{\partial k}{\partial y}\right] \\
\mu_{\mathrm{t}}= & c_{\mu} f_{\mu} \rho V \bar{k} L
\end{aligned}
$$

境界条件は，管壁 $(r=D / 2)$ で $k=L=0$, 中心 $(r$ =0)で $\partial k / \partial r=\partial(k L) / \partial r=0$ である. これらの式に 現われる定数は，以下のように評価できる.

発達した乱流境界層では対数速度分布

$$
u^{+}=(1 / \kappa) \ln y^{+}+B
$$

第 1 表 $k-\varepsilon$ モデルの定数

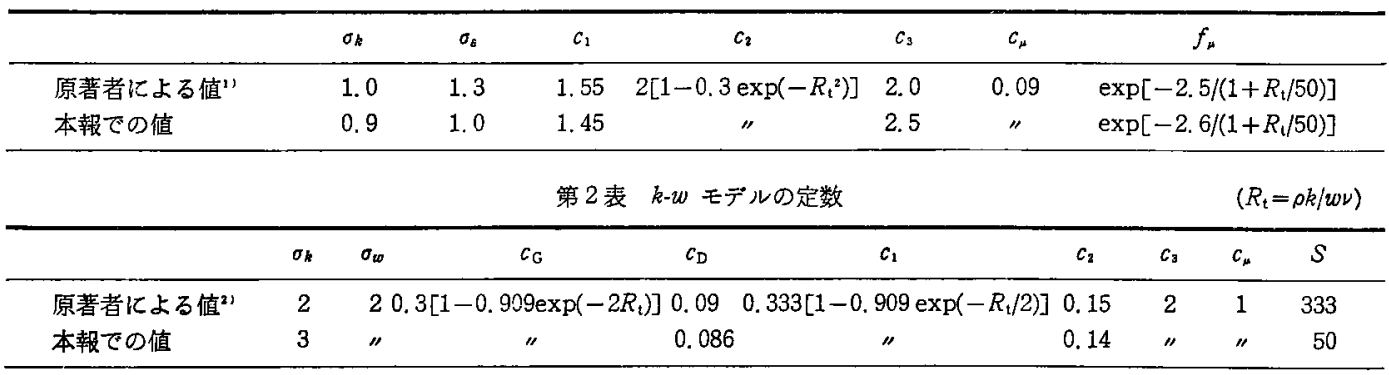


が成立するから，乱流粘性係数は $\mu_{\mathrm{t}} \simeq \rho \kappa y u^{*}$ となり， 式(10)加 $k / u^{* 2}=(\kappa y / L)^{2} / c_{\mu}{ }^{2}$ をうる. 特性長 $L$ の とり方には比例定数分だけの自由度があるので，との 領域で $L=\kappa y$ とする. 他方実験的に $k / u^{* 2} \simeq 3$ であ るととが知られているから， $c_{\mu} \simeq 0.58$ を得る.

またこの発達した乱流境界層内では乱れの発生と消 隇が局所的にほぼ平衡しているので，式（８）の右辺第 二項と第三項を等置し $\tau, k=\left(c_{u} / c_{\mathrm{D}}\right) L^{2}(\partial \bar{u} / \partial y)^{2}$ を得 る. ここで再び対数速度分布式(11)を仮定すれば，

$$
k / u^{* 2}=\left(c_{\mu} / c_{\mathrm{D}}\right)(L / \kappa y)^{2}
$$

となり， $L=\kappa y, k / u^{* 2} \simeq 3$ とすると, $c_{\mathrm{D}} \simeq 0.19$ を得 る.

係数 $c_{2}$ は，グリッド後流の等方性乱流の減衰から 定められる．とのとき，乱れがグリッドからの距離 $x$ に対し $x^{-n}$ で減衰するとすれば，式(8)と（9)で対流 項と消隇項のみを考えることにより，c2=(1. $5 n-1) / n$ となることが導かれる．とこでnについての定説はな いが, 乱流レイノルズ数 $\left(R_{\mathrm{t}}\right)$ の大きな範囲では $n \simeq$ 1. 25，小さな範囲では $n \simeq 2.5$ である. ゆえに， $c_{2}=$ $0.7\left[1+0.57 e^{\left.-\left(R_{\mathrm{t}} / 3\right)^{2}\right]}\right.$ が得られる. 他方 $c_{1}$ は，一様 せん断流中での相関関数の測定值から， $c_{1} \simeq 1.2$ 亡な $\Xi^{3)}$.

対数速度分布の成立する領域に式 $(9)$ をあてはめ， 粘性，対流項，曲率を無視し，式(10)，(12) 之 $L=\kappa y$ の関係を用いると，カルマン定数 $\kappa$ と他の係数の関係 を与える式

$$
\kappa^{2}=\left(c_{1}-c_{2}\right) /\left(2 c_{3}-c_{\mu} / c_{\mathrm{D}} \sigma_{L}\right)
$$

を得る ${ }^{3)}$ ，乙れが $c_{3}$ を与える式となる．容易にわか るように， $c_{1}>c_{2}$ であるがり $c_{3}$ を導入しないと実 数の $\kappa$ を得るととができない.

式(8)の右讱最終項は，式(2)の右讱最終項之同じ 手法で，粘性の効果を考虑するために導入したもので ある. 乱流エネルギーは壁近傍で $k \propto y^{2}$ となるとと 加ら，粘性をとり入れた搪散項 $\mu \partial^{2} k / \partial y^{2}$ は壁近傍で ゼロとならない，そこでこれを補償するため，右匄最 終項を導入した. HANJALIC-LAUNDER ${ }^{4)}$ によれば，式 (2)の $2 \mu(\partial \sqrt{k} / \partial y)^{2}$ は乱流散逸の非等方的な部分, $\rho \varepsilon$ は等方的な部分之解瀵されている。すすなわち全散 逸 $\varepsilon_{\text {total }}$ は

$$
\rho \varepsilon_{\text {total }}=\rho \varepsilon+2 \mu(\partial V \bar{k} / \partial y)^{2}
$$

である. このとき壁近傍では， $a, b$ を適当な定数とし $\tau$

$$
\begin{aligned}
& k=a y^{2}+b y^{3}+O\left(y^{4}\right) \\
& \rho \varepsilon=2 \mu a+4 \mu b y+O\left(y^{2}\right)
\end{aligned}
$$

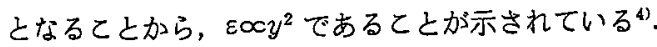

他方 HoFFMAN ${ }^{5)}$ は， $2 \mu(\partial \sqrt{k} / \partial y)^{2}$ の代りに $(\mu / y)$. $(\partial k / \partial y)$ としても同様に $k \propto y^{2}$ なる分布が得られ，し かむこのほうが数值計算の収束がはやいてとを示し たそこてで本報では後者に従うこととする，ただし， このとき式(15)によればをは壁近傍ではyに比例し， ゆえに, $\varepsilon=c_{\mathrm{D}} k^{3 / 2} / L$ から $L \propto y^{2}$ となるととが要求 される。

式(9)の右辺最終項は，式(8)の右辺最終項们対応 して次元的考察から新たに導入したあのである. 壁近 傍では $k L \propto y^{4}$ となるととから， $k L$ の拡散項とc4を 含む項とが等しくなるためには， $c_{4}=6$ でなりればな らない。

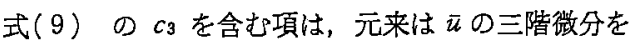
含む項であった。しかし三階微分を含む形は計算時間 を要しかつ数值解の不安定の原因となることが見いだ された，そこで，対数速度分布式 (11) に対しては $d^{3} \bar{u} / d y^{3}=\left(2 / y^{2}\right) d \bar{u} / d y$ 加成立するてと加，式(9) に示す形を採用した．てれによってての項に起因する 不安定が消え，収束むはやくなった。

以上の推定值をむとに，実際の計算を通して定めた 定数か第 3 表の $(\mathrm{A})$ 打よび (B) である. 定数 $(\mathrm{A})$ と (B)の主な差異は，(A)では $c_{1}$ が一定値であるのに 対し，(B)では乱流レイノルズ数の関数になっている

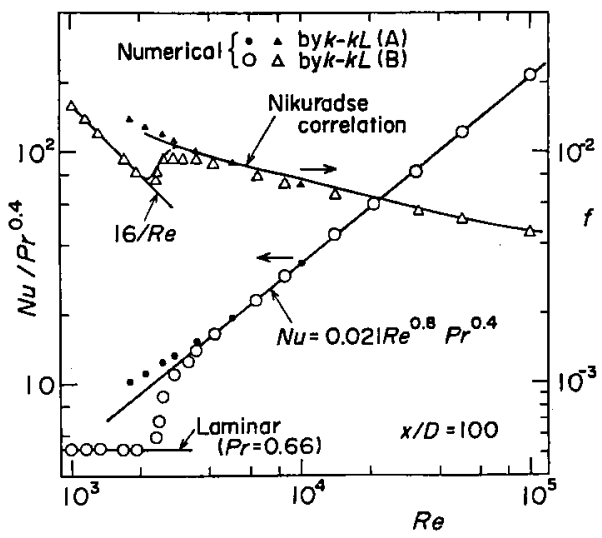

\begin{tabular}{|c|c|c|c|c|c|c|c|c|c|c|c|}
\hline & $\sigma_{k}$ & $o_{L}$ & $c_{\mathrm{D}}$ & & $c_{2}$ & & $c_{2}$ & $c_{3}$ & $c_{4}$ & $c_{*}$ & $f_{\mu}$ \\
\hline 推 定 值 & - & - & 0.19 & & 1.2 & $0.7[1+0.57 \mathrm{ex}$ & $\exp \left\{-\left(R_{\mathrm{t}} / 3\right)^{2}\right\}$ & 式(13) & 6 & 0.58 & - \\
\hline 本報での値(A) & 1.0 & 1.3 & 0.15 & & 1. 27 & & $"$ & 3.2 & $"$ & 0.61 & $-0.8 \exp \left\{-\left(R_{\mathrm{t}} / 20\right)^{2}\right\}$ \\
\hline (B) & 1.0 & 1.5 & $"$ & 1. $3[1-0$. & $55 \exp \{$ & $\left\{-\left(R_{\mathrm{t}} / 8.35\right)^{4}\right\}$ & $"$ & 3.1 & $"$ & $" 1$ & $-0.7 \exp \left\{-\left(R_{t} / 20\right)^{2}\right\}$ \\
\hline
\end{tabular}

第 1 図 物性值変化のない場合の熱伝達率之管摩擦係数 ( $k-k L$ モデル，定数(A)(B)kよる)

第 3 表 $k-k L$ モデルの定数

$\left(R_{\mathrm{t}}=\sqrt{k} L / \nu\right)$ 
点にある. これらの定数を用い，物性値変化のない流 れについて熱伝達率と管摩擦係数を求めたのが第 1 図 である. 定数(A),(B)による結果仙ともに，Re己 4,000ではほぽよい值を与える. しかしレイノルズ数 が低くなっても，定数(A)による結果(黒印)は層流の 值に近づく傾向をみせない，他方，定数（B)による結 果（白印）は，低レイ/ルズ数に対して改善されてい る. 以下では $k-k L$ モデルというとき，との(B)の 定数を用いる.

\section{3. 数值計算の手法}

前節で述べたモデルの各組の式を，通常の連続の 式，運動方程式，エネルギー式と連立させて解いた。 境界条件は， $r=0$ で $\partial \bar{u} / \partial r=\partial \bar{T} / \partial r=\overline{\rho v}=0, r=D / 2$ で $\bar{u}=\overline{\rho v}=0, \partial \bar{T} / \partial r=q_{\mathrm{w}} / \lambda_{\mathrm{w}}$ である. 加熱開始点 $(x=0)$ では， $\bar{T}=T_{\mathrm{in}}, \bar{u}$ は十分発達した等温流の分 布をすつした．エネルギー式に現われる乱流熱伝導 率 $\lambda_{\mathrm{t}}$ は，乱流プラントル数 $\sigma_{T}$ を介して $\lambda_{\mathrm{t}}=\mu_{\mathrm{t}} c_{\mathrm{P}} / \sigma_{T}$ とし， $\sigma_{T}$ は 0.9 で一定とした.

数值解は差分法によって求めた，半径方向のメッシ ュは，壁近傍で細かく，中心部ではあらくする必要が ある，そこで，壁加ら中心沉むかって等比級数的に增 大するようにメッシュ幅を変え，また中心付近ではメ ッシュ幅がある一定值（直径の 1 2\%）上り大きく ならないようにした，その結果，壁佰す近いメッシ 工点を $y^{+}=1$ としてあ，全体の半径方向メッシュ数 は 40〜70 となった。它し等間隔にメッシュを切れ ば，数百以上のメッシュ数が必要となる.

なお，てのような不等間隔メッシュに対しては，ラ プラシアンの特殊な差分式を用いる必要がある。乙れ については，文献 6) に差分式を与元だ.

$x$ 方向の微分 $\hat{\partial} \bar{u} / \partial x, \partial k / \partial x$ 等は後退差分とし，陰 伏法によって解いた， $x$ 方向に 1 メッシュ進むでとに イテレーションを行なうととになるが，いわゆる加速 係数を導入するよりあ，むしろイテレーションでとに 新しい解之古い解の平均をとるような“減速”を行な うほうが速く収束した，計算時間は，物性値変化のな い場合で約 $5 \sim 10$ 秒，物性值変化を考慮した場合は約 5〜10 分を要した（FACOM 230-75 による).

\section{4. 円管内ガス流への適用}

4.1 物性值変化のない場合 加熱流の計算に先だ ち，物性值変化のない乱流住対して各モデルが妥当な 結果を与えることを確認する必要がある，第2 図㤝， 流速分布の計算值を普遍速度分布上比較したものであ

* 文献 6) の第 1 表のラプラシアンの差分式中, $B_{k}$ の式に おりる $+\left(E_{k} / r_{k}\right) R$ は $-\left(E_{k} / r_{k}\right) R$ の誤記である.

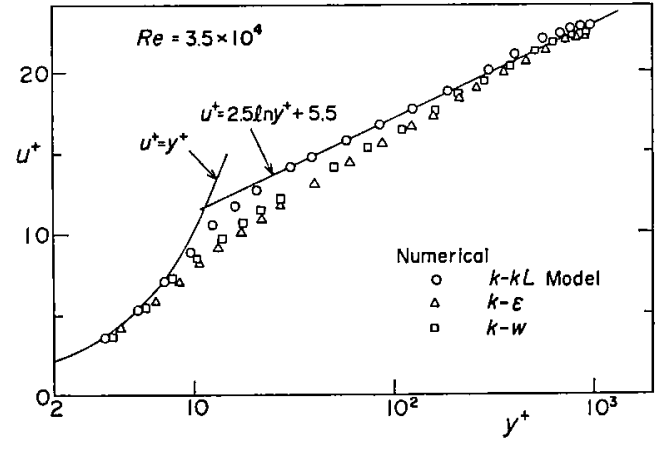

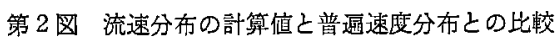
(等温流)

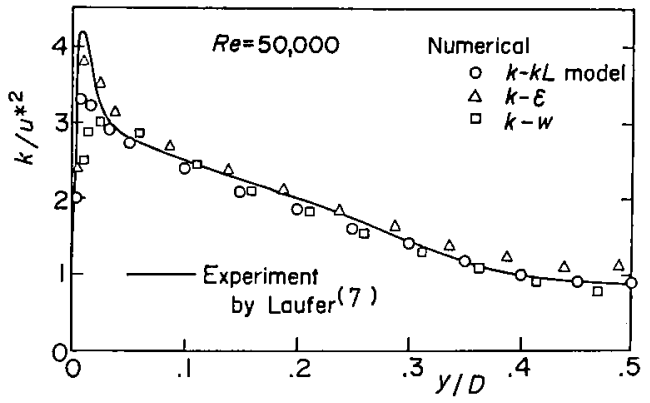

第 3 図 乱流エネルギーの実験値"この此较 (等温流)

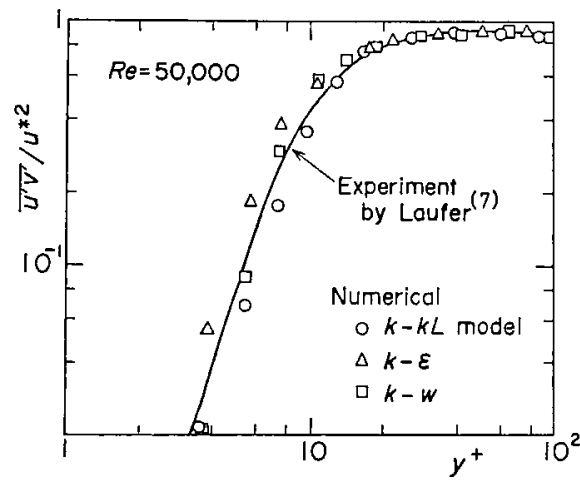

第 4 図 レイノルズ応力の実験值 ${ }^{7}$ との比校 (等温流)

る.第 3 図，第 4 図は，乱流エネルギーおよびレイノ ルズ応力の計算值を， LAUFER ${ }^{7)}$ の実験值と比較した あのである. てのように，いずれのモデルあ定数を適 当に選ふてとによって，等温流に対しては罗当な結果 を与えることがわかる。

4.2 加熱ガス流への適用 円管内ガス乱流を高い 熱流束で加熱した場合䎲いて， $k-\varepsilon, k-w, k-k L$ の 各モデルと混合長理諭による計算值を PERKINS \& WORSOE-SCHMIDT ${ }^{87}$ の実験値と比較し，第 5 困に示 す.図のたて軸は

$C_{N u_{\mathrm{b}}}=N u_{\mathrm{b}} / \operatorname{Re}_{\mathrm{b}}{ }^{0.8} \operatorname{Pr}_{\mathrm{b}^{0.4}}$ 


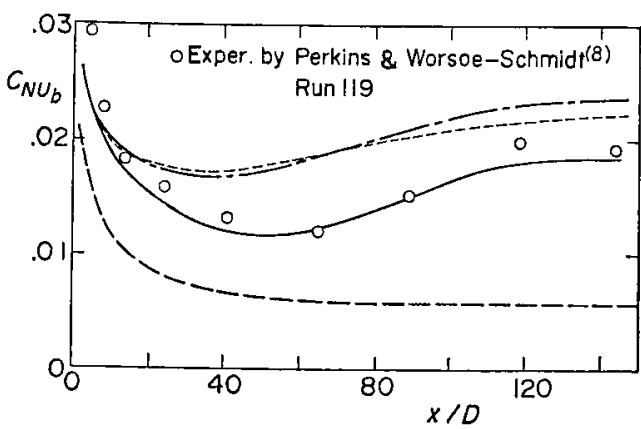

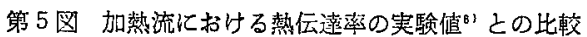
$R e_{\text {in }}=18,700, q_{\text {in }}{ }^{+}=0.00415, T_{\text {in }}=107 \mathrm{~K}\left(\mathrm{~N}_{2}\right)$ $-k-k L,-\longrightarrow k-\varepsilon,-\cdots-k$, ……... 混合長モデル

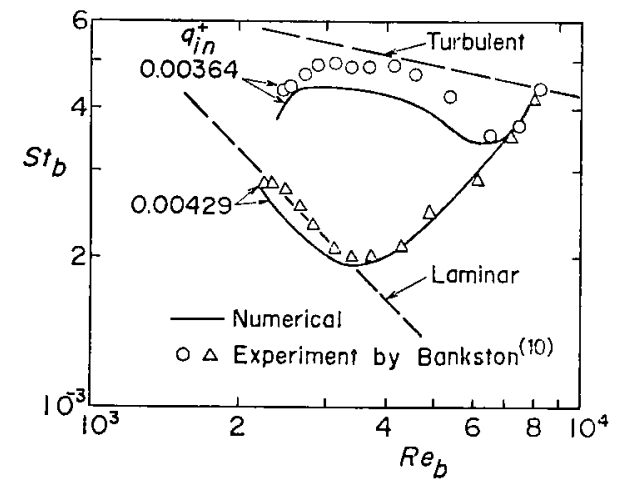

第 6 図 首流化を含む実験 ${ }^{10}$ との比較 $(k-k L$ モデル) $R e_{\mathrm{in}} \simeq 8,500, \quad T_{\mathrm{in}} \simeq 75 \mathrm{~K}\left(\mathrm{H}_{3}\right)$

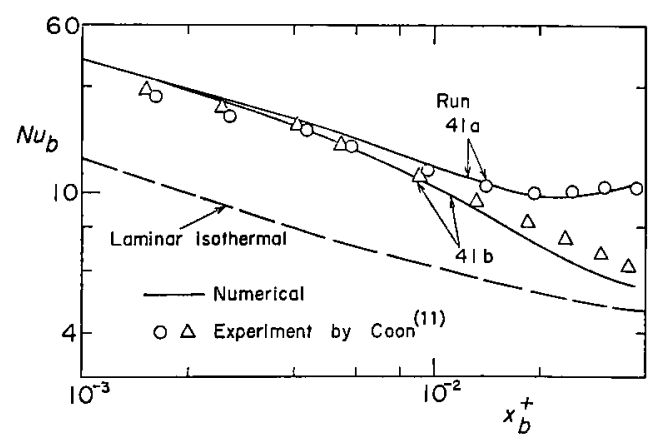

第 7 図 層流化を含む実驗 ${ }^{11}$ との比较 $(k-k L$ モデル)

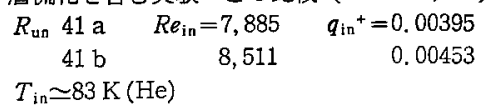

である，添字 bは，物性值を流体のバルク温度（混合

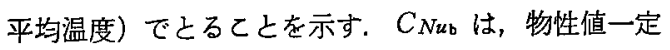
の発達した乱流に対しては約 0.021 となるべきことが 知られているが，第 5 図の実験值は，加熱のために大 きく低下している.

計算值のうちまず混合長モデル（点線）についてみ るととれは MCELIGOT ${ }^{92}$ が各種の混合長モデルを

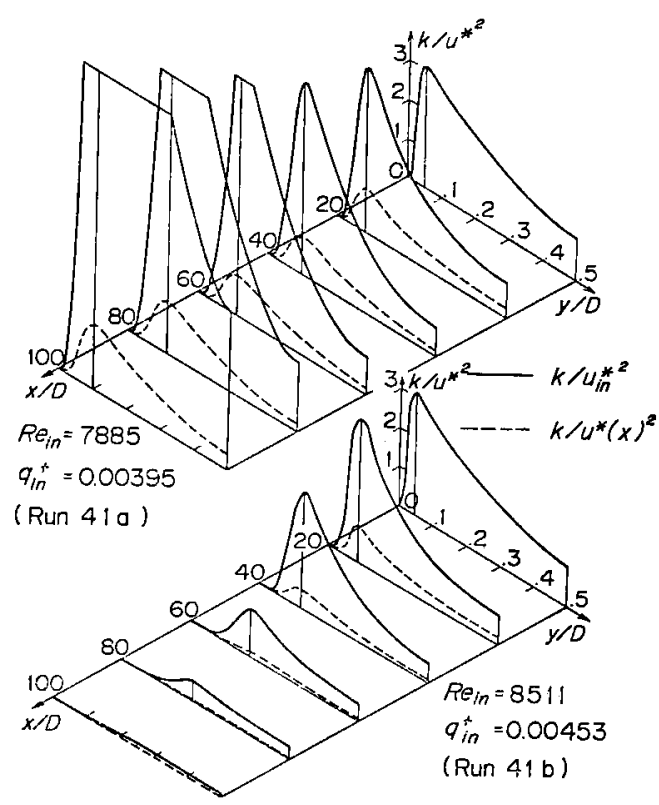

第 8 図第 7 図の場合におりる乱流エネルギーの軕方向 および半径方向分柿

比较したなかで最良の結果を与えるとしたいわゆる “van Driest 壁面”方式によるものである，にもかか わらず，混合長モデルによる結果は実験結果よりかな り大きい. 元来, 混合長モデルでは乱れの発生と消滅 の平衡を仮定しているから，この種の非平衡度の強い 流れに適用するには無理があると考えられる。

3 種類の二方程式モデルについてみると，これらは 等温流れに対しては同じように良好な結果を与えたに あかかからず，加熱流に適用すると，必ずしもよい結 果を与えない，今回比較したなかでは本報で開発した $k-k L$ モデルが相対的に最良の結果を与えるので，以 下では $k-k L$ モデルについてのみ検討を続ける.

第 6 図，第 7 図は，BANKSTON ${ }^{10)}$ とCOON ${ }^{11)}$ の実 験結果との比較である。これらの実験例はともに，入 口条件がほぼ同一であるにもかかわらず，下流での熱 伝達率が大きく異なる例としてよく知られている。加 枉が弱いほうの実験（第 6 図の $q_{\text {in }}{ }^{+}=0.00364$ 之第 7 図の Run 41 a) では，熱伝達率は一度娍少したのち 再び増加して通常の乱流の関係式に近つく，他方加熱 が強いほうの赛騒（第 6 図の $q_{\text {in }}{ }^{+}=0.00429$ ，第 7 図 の Run 41 b) では，熱伝達率は流枋向に減少し続 けて層流に対する值に近づく，とれが層流化の発生で ある。これらの傾向は，今回の $k-k L$ モデルによっ てよく再現される。

第 7 図の場合について，k-kL モデルで計算された 乱流エネルギーの分杵を第 8 図に示す．実線は乱流エ ネルギー $k$ を入口での摩擦速度 $\boldsymbol{u}_{\mathrm{in}}$ * で規格化したす 
ので，いわば $k$ の絶対值の変化代対芯する. 破線は $k$ を各 $x$ での $u^{*}$ で挸格化したすので， $k$ の相対值の 変化を示す，Run 41 a では，下流で $k$ の絶対值が增 大しているが，乙れは加熱汇っって主流加加速される ためである. Run $41 \mathrm{~b}$ では $k$ の絶対值，相対值とも に隇少して㧍り，てれが第7図における熱伝達率低下 の直接の原因である、乙の場合, 出ロレイノルズ数は まだ約 4,100であるにむかかわらず，乱流粘性係数は 分子粘性係数よりむ小さくなっており，流れは層流化 したといえる.

\section{5. あとがき}

以上，二方程式 $k-k L$ モデルを粘性の効果を含む 形に㹡張し，定数を定め，層流化を含む高熱流束加熱 ガス流の実験結果と比較した，計算の結果は， $q_{\text {in }}{ }^{+} \lesssim$ 0.007 に対し，許容できる誤差の範囲内で夷験值と一 致した.

以上の計算は，前述したように第 3 表の(B)の定数 によるものである. 定数 (A)を用いると，層流化しな い場合の熱伝達率の低下は予測できたが，層流化に至 る過程は再現できなかった．このように，定数 $c$ は， 乱流から層流への遷移過程の計算結果に大きな影響を あつことがわかった。

既存の $k-\varepsilon, k-w$ モデルは，等温流については同様 によい結果を与えたにもかかわらず，加熱流们適用す る之満足すべき結果を与えない，上述の点が明らかに なってみると，乙の理由は，てれらのモデルの本質的 な欠宿というょりは，むしろ定数の定め方によると考 えられる.したがってモデルの定数，具体的には $k-\varepsilon$ モデルの $c_{1}, k-w$ モデルの $c_{\mathrm{G}}, c_{1}$ を適正化するとと により，これらのモデルでもよい結果の得られる可能 性が大きいといえる.

最後に，この種のモデルで遷移が扱えるであろうか という根本的な問題の検討が必要であろう．この種の モデルで計算をしているのは，結局は乱流エネルギー のバランスである．他方周知のように，層流加乱流 への遷移は乱れの不安定によってひき起てされ，エネ ルギーバランスによるわけではない，したがって筆者 あ，層流から乱流への遷移，すなわち乱れの発生がて の種の手法で解析できるとは考えていない.

しかし，すでに安定な乱流が存在する状態からの僄 移，すなわちててで扱った層流化のような場合には事 情が異なり，乱れのエネルギーバランスが主要な役割 をはたしている．したがってての種のモデル解析む妥 当性を有するのではないか，というのが䈉者の現在の 考えである，諸賢からのご教示をいただければ幸いで ある。

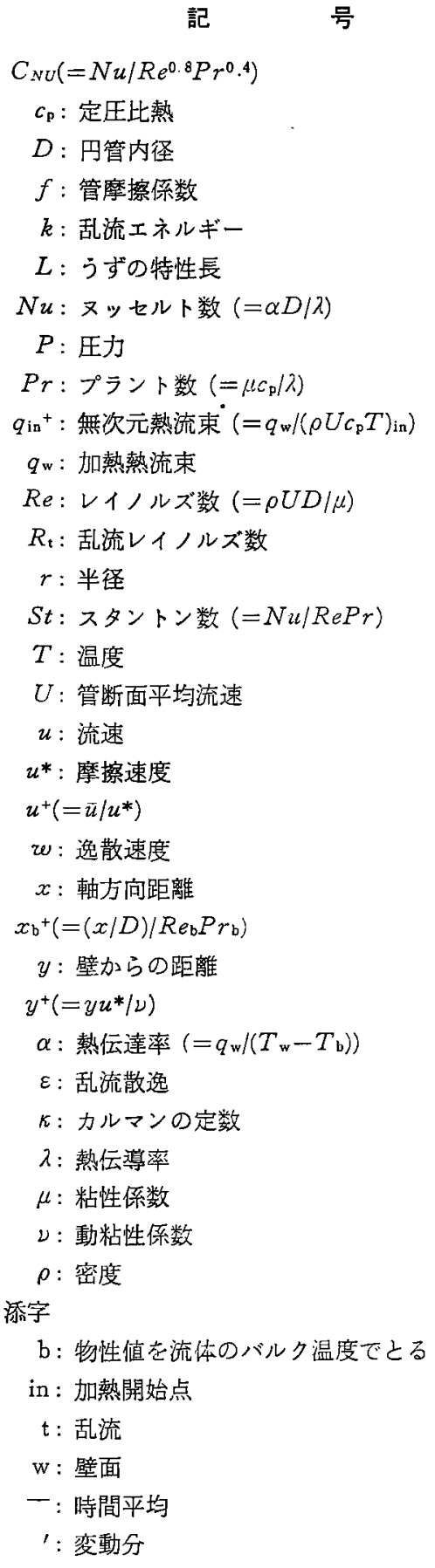

参考文献

1) Jones, W.P. and Launder, B.E.: The Prediction of Laminarization with a Two-Equation Model of Turbulence, Int. J. Heat Mass Transfer, Vol. 15, No. 2 (1972), pp. 301-314.

2) Wilcox, D.C. and Traci, R.M.: A. Complete Model of Turbulence, AIAA Paper No. 761-351 
(1976).

3) Rotta, J.C.: Turbulente Strömungen, Teubner, Stuttgart (1972); 大路通雄訳：乱流，岩波畵店 (1975).

4) Hanjalic, K. and Launder, B.E.: Contribution towards a ReYNolds-Stress Closure for LowReynolds-Number Turbulence, J. Fluid Mechanics, Vol. 74, Part 4 (1976), pp. 593-610.

5) Hoffman, G.H.: Improved Form of the LowREYNoLds Number $k-\varepsilon$ Turbulence Model, Phys. Fluids, Vol. 18, No. 3 (1975), pp. 309-312.

6) 河村 洋: 二重円管内乱流への非定常熱伝達の解析 (第 1 報)，日本機械学会論文集，第 39 巻，第 324 号 (1973), pp. 2498-2511.

7) Laufer, J.: The Structure of Turbulence in Fully Developed Pipe Flow, NACA Report 1174 (1954).

8) Perkins, H.C. and Worsoe-Schmidt, P. : Turbu- lent Heat and Momentum Transfer for Gases in a Circular Tube at Wall to Bulk Temperature Ratios to Seven, AEC Report SU 247-7 (1964).

9) McEligot, D. M., Smith, S. B. and Bankston, C. A. : Quasi-Developed Turbulent Pipe Flow with Heat Transfer, J. of Heat Transfer, Vol. 92, No. 4 (1970), pp. 641-650.

10) Bankston, C. A. : The Transition from Turbulent to Laminar Gas Flow in a Heated Pipe, J. of Heat Transfer, Vol. 92, No. 4 (1970), pp. 569579.

11) Coon, C. W. : The Transition from the Turbulent to the Laminar Regime for Internal Convective Flow with Large Property Variations, Ph. D. Dissertation, The University of Arizona, Tucson, Arizona (1978).

\section{乱流噴流の数 值 解 析*}

\section{1. まえがき}

近年のコンピュータの発達はめざましい，スーパー コンピュータをひきあいに出すまですなく，最近発表 された国産中型機でも 3 年前の同価格機に比較して計 算速度 2 倍強，記憶容量 10 倍以上となっており，と のペースはもうしばらく続きそうである。乱流境界首 の偏微分方程式が直接解加れるようになったのはそう 古い話ではなく十数年来のととであるが，コンピュー 夕の進歩によりいまや Large Eddy Simulation のよ うな格子単位でモデル化するあのまで扱われるように なった．しかし比較的簡単な流れでは混合距離などの 低次のモデルがよく整備されており，工学計算には十 分であるという場合む多いので，すべてに大型モデル を用いるのは“牛刀・鴊肉”に類するすのであるう.

したがってわが国においてす各モデルの有効性と限 界，経験定数の決定，計算アルゴリズム等の乱流モデ ル計算の諸側面に関しての経験や情報の蓄積, 収集, 整備をはかり，目的に応じた乱流計算の最適設計に役 立てる必要があるう。

さててれから述べる噴流の計算に用いた 2 方程式モ デルは乱れの速度之長さのスケールのモデル微分方程 式をたて，渦粘性を通して平均流と連立するものであ

* 昭和 54 年 4 月 6 日，日本航空宇笛学会第 10 期年会シン ポジウムにて丵演. 昭和 54 年 8 月 3 日原稿受理 A Numerical Calculation of Turbulent Jet

** 航空守宙技術研觉所角田支所 Hirosi IsIGAKI
石垣 博**

る. 速度スケールに乱れエネルギー $k$ を採用するのは 各研究者の一致したとてろであるが, 長さスケール そのあのの使用はあまり成功を収めず， $k l, k / l^{2}, k^{3 / 2} / l$ などについて式が立てら行計算が行なわれている。 こ こで用いるのは 3 番目のもので，乱れエネルギーの散 逸 $\varepsilon$ がエネルギー渦 (Energy Containing Eddy)の 関係 $\varepsilon \sim k^{3 / 2} / l$ 加ら決まるととを利用して， $\varepsilon$ の式を 解いて散冕長さ $l_{\varepsilon} \equiv k^{3 / 2} / \varepsilon$ を用いる，いわゆる $k-\varepsilon$ モ デルである．ここで述べる計算例は 2 次元噴流の発達 領域を主眼として行ない，比較的豊富な実験データと の比較，検討を行なって，さらに複雑な乱流解析への 知見を得ようとしたものであるが，その前に次節で自 由乱流の計算法を概観してみるととにする。

\section{2. 自由乱流における計算法の概観}

乱流の計算は BOUSINESQ，REYNOLDS の時代からの 目標であったが，実際に運動量の式を解いて計算が行 なわれるようになったのは，PRANDTL の混合距離モ デルの発表 (1925) 以来といえるであろう，乱流噴流 の速度分布が最初に計算されたのむ，混合距離モデル を用いた TOLLMIEN (1926)によってであった。しか し湿合距離 $l_{\mathrm{m}}$ を断面内で一定とすると，渦動粘性係 数 $\nu_{\mathrm{T}}=l_{\mathrm{m}}{ }^{2} \partial U / \partial y$ 蛙噴流中央でゼロとなり，速度分布 は特異性を帯びる. このため PRANDTL (1942) は第 2 のモデル $\nu \tau \propto \delta \Delta U$ ( $\delta$ : 噴流幅， $\Delta U$ : 速度差）を提 案し，GöRTLER (1942)により計算が行なわれたが, 速度分布の尖り部は平らになったものの全体的には著 